\title{
Kajian Literatur Sistematis: Skema Pengendalian Biaya dalam Asuransi Kesehatan Nasional di Beberapa Negara
}

\section{Cost Containment Application in The National Health Insurance Scheme: A Systematic Review}

\author{
Eka Pujiyanti ${ }^{1,2,3}$, Ery Setiawan ${ }^{1}$, Euis Ratna Sari ${ }^{1}$, Indah Pratiwi Suwandi ${ }^{3}$ \\ ${ }^{1}$ Center for Health Economics and Policy Studies, Faculty of Public Health, Universitas Indonesia, Depok, Indonesia \\ 2Program Doktoral IImu Kesehatan Masyarakat, Fakultas Kesehatan Masyarakat, Universitas Indonesia, Depok, Indonesia \\ ${ }^{3}$ Rumah Sakit Universitas Indonesia, Depok, Indonesia
}

Korespondensi: Eka Pujiyanti

e-mail:eka.pyanti@gmail.com

\begin{abstract}
Abstrak
Pengendalian biaya merupakan salah satu dari beberapa strategi untuk memastikan keseimbangan finansial dari skema asuransi kesehatan nasional. Beberapa model pengendalian biaya yang umum digunakan secara global yaitu seperti cost-sharing, capping, dan sebagainya. Review ini dilakukan dengan tujuan untuk menentukan biaya dan dampak dari implementasi skema kebijakan sebagai instrumen pengendalian biaya di berbagai negara. Review sistematis dilakukan dengan mengambil data dari beberapa database yaitu Proquest, Pubmed, dan Cochrane Library dengan intervensi utamanya yaitu menggunakan metode cost-sharing. Hasil dari review difokuskan pada skema pengendalian biaya dari perspektif pemerintah, yaitu lingkup asuransi sosial yang dapat berupa modifikasi sistem pembayaran, cost-sharing, capping/quota, dan waiting period. Berdasarkan salah satu studi di Kanada, dapat dilihat bahwa dihasilkan dampak yang signifikan pada sistem kesehatan, mengurangi pengeluaran dan penggunaan obat yang tidak esensial, serta secara tidak langsung meningkatkan efisiensi pasar obat melalui kepedulian peserta dalam penggunan obat. Dalam penelitian ini dapat disimpulkan bahwa implementasi dari skema pengendalian biaya dapat mengurangi risiko bahaya dari perspektif peserta dengan kontribusi tambahan pada penggunaan pelayanan kesehatan.
\end{abstract}

Kata kunci: JKN, strategic health purchasing, prospective payment, cost containment

\begin{abstract}
Cost-containment is one of several strategies to ensure the financial sustainability of the National Health Insurance scheme. Several cost-containment models were commonly globally, such as cost-sharing, capping, and others. This review aims to determine the costs and impacts of implemented policy schemes as cost-containment instruments in various countries. We performed a systematic review from several primary databases (Proquest, Pubmed, and Cochrane Library) with the primary intervention are the cost-sharing methods. The results of our review focused on the cost containment scheme from the government perspective, in which the context of social insurance can be a modification of payment systems, cost-sharing, capping/quota, and waiting period. From one of the studies in Canada, we can see that the result has a significant impact on the health system, reducing the expenditure and the use of drugs that are not essential, and also indirectly improve the technical efficiency of the drug market through the care of participants in drug utilisation. In this research, it can be concluded that the implementation of cost containment schemes can reduce the moral hazard risk from the perspective of participants with additional contributions to the utilisation of healthcare services.

Keywords: JKN, strategic health purchasing, prospective payment, cost containment

\section{Pendahuluan}

Sistem Jaminan Sosial Nasional (SJSN) yang diterapkan di Indonesia merupakan salah satu

upaya dari pemerintah untuk meningkatkan akses ke pelayanan kesehatan dan memberikan penjaminan secara penuh terhadap kebutuhan dasar hidup secara layak
\end{abstract}


bagi peserta maupun anggota keluarganya seperti yang telah dijelaskan dalam UU Nomor 40 Tahun 2004 tentang Sistem Jaminan Sosial Nasional. Salah satu bentuk jaminan yang diterapkan secara nasional adalah jaminan kesehatan yang merupakan perlindungan dan pemeliharaan kesehatan untuk pemenuhan kebutuhan dasar masyrakat terhadap kesehatan dengan dilakukan penarikan iuran yang dibayar secara pribadi maupun oleh pemerintah seperti yang telah dijelaskan pada Peraturan BPJS Kesehatan Nomor 1 Tahun 2014 tentang Penyelenggaran Jaminan Kesehatan. Peningkatan akses terhadap pelayanan kesehatan diantara peserta asuransi dapat dipandang sebagai efek yang juga dapat meningkatkan kunjungan pasien ke fasilitas pelayanan kesehatan seperti rumah sakit (Hadiyati et al., 2017).

Peningkatan pelayanan kesehatan dapat dilihat pula sebagai efek yang negatif jika peningkatan tersebut disebabkan oleh perilaku yang kurang "bertanggung jawab" (moral hazard) baik oleh peserta maupun penyedia pelayanan kesehatan (provider). Menurut Morissey (2008) Moral hazard adalah kerugian yang timbul akibat kelalaian yang disengaja oleh peserta asuransi untuk mendapatkan keuntungan dari polis asuransinya, peserta asuransi dengan sengaja berniat untuk tidak menjaga kesehatannya (Heryana, 2013). Perilaku moral hazard dapat meningkatkan biaya kesehatan sehingga terjadinya inflasi pada sektor kesehatan, terdapat beberapa faktor lain yang menyebabk inflasi pada kesehatan diantaranya adalah; inflasi harga di masyarakat akan ikut meningkatkan biaya investasi dan biaya operasional pelayanan kesehatan, meningkatnya kuantitas (jumlah) dan kualitas penduduk, kemajuan ilmu dan teknologi sehingga investasi terhadap biaya peralatan kesehatan juga menjadi tinggi, pergeseran pola penyakit dari yang akut menjadi kronis sehingga membutuhkan waktu perawatan lebih lama, terbentuknya spesialisasi dan sub-spesialisasi pada pelayanan kesehatan (fragemented health service), dan sebagainya (Setyawan, 2015). Peningkatan biaya kesehatan (inflasi biaya kesehatan) juga dapat terjadi dari pengaruh dua sisi yaitu sisi supply yaitu penyedia pelayanan kesehatan, tenaga medis, teknologi kedokteran, dan sebagainya. Selain itu juga terdapat pengaruh dari segi demand yaitu pemfaatan pelayanan kesehatan, transisi epidemiologis penyakit, dan sebagainya. Dikarenakan adanya pengaruh dari sisi supply dan demand tersebut, sehingga diperlukan teknik pengendalian biaya (cost containment) pada pelayanan kesehatan (Gani, 1996).

Strategi pembiayaan (strategic purchasing) merupakan kegiatan yang mencakup hubungan provider payment terhadap informasi, seperti performa provider atau kebutuhan kesehatan penduduk, menyelaraskan pendanaan dan pendapatan untuk mencapai peningkatan efisiensi, akuntabilitas, pengiriman layanan, dan ekuitas (Feldhaus and Mathauer, 2018). Strategic purchasing dan provider-payment method yang baik dibutuhkan dalam organisasi untuk mendukung efficiency, costcontainment, dan equity outcomes (Tangcharoensathien et al., 2018). Beberapa strategic purchasing yang dilakukan di berbagai negara dalam upaya untuk mencapai Universal Health Coverage seperti pada Gambar 1 (Counte et al., 2019) 


\section{Gambar 1. Model Pembayaran di Pelayanan Kesehatan Berbagai Negara}

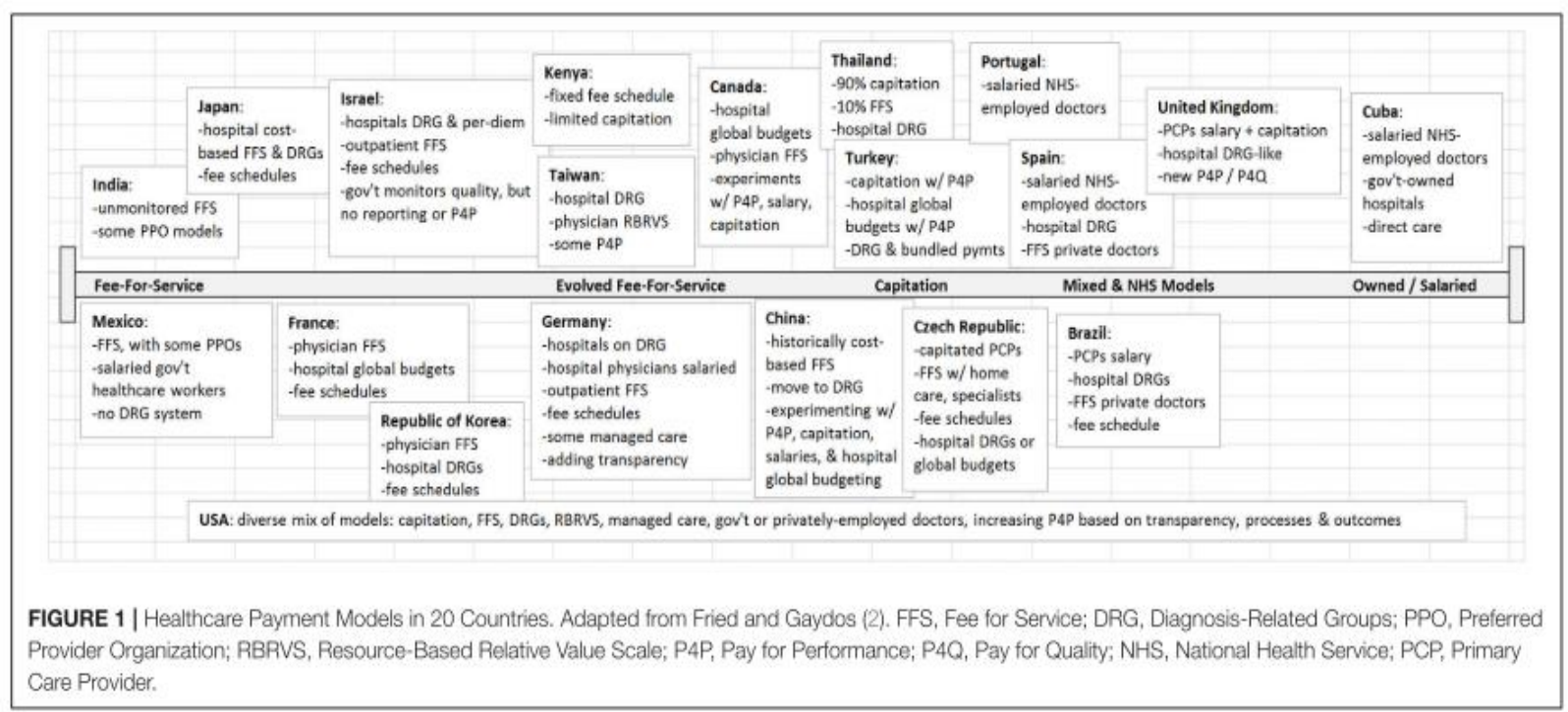

(Sumber : Bentuk-Bentuk Pengendalian Negara dikutip dari buku "Paying for Performance in Health Care")

Dalam rangka mengantisipasi terjadinya efek negatif pada program asuransi maka diperlukan upaya pengendalian biaya. Berbagai instrumen pengendalian biaya kini telah tersedia dan banyak diadopsi oleh badan pengelola asuransi. Pada program asuransi yang mengadopsi managed care, upaya pengendalian biaya kesehatan dapat dilakukan melalui intervensi pada sisi demand (peserta asuransi), sisi supply (penyedia layanan kesehatan/providers), atau kedua-duanya. Intervensi pada sisi demand dapat dilakukan dengan menerapkan iurbiaya (cost-sharing). Iur biaya merupakan wujud keterlibatan peserta asuransi (tertanggung) dalam pembiayaan kesehatan. Wujud tersebut dibuktikan dengan keterlibatan peserta untuk membayar sejumlah biaya tertentu atas pelayanan kesehatan yang mereka gunakan. BPJS Kesehatan sebagai salah satu pihak asuransi memiliki kemampuan untuk dapat menghasilkan pendapatan yang tinggi, oleh karena itu disebut dapat mengelola supply dan demand dalam pelayanan kesehatan,

Deductible merupakan jumlah biaya kesehatan yang harus dibayar oleh peserta serta mempengaruhi tingkat keberhasilan dari penerapan konsep SJSN (Janis, no date).

Aturan mengenai asuransi dikelola oleh badan pengelola asuransi dan harus dipahami oleh peserta asuransi, serta tertulis jelas dalam kebijakan cost-sharing untuk menciptakan penggunaan pelayanan kesehatan yang optimal, tidak berlebih dan tidak kurang dengan mencegah terjadinya pemakaian layanan yang berlebih dan sesungguhnya tidak diperlukan. Menurut Liu dan Mills (2007), metode pembayaran yang dilakukan oleh penyedia pelayanan kesehatan (PPK) seharusnya dapat mengarahkan menuju kendali biaya, jaminan mutu, dan efisiensi internal, serta tidak memberikan insentif atau keuntungan kepada PPK yang memberikan pelayanan berlebihan maupun sebaliknya (Aden, 2012). Jenis-jenis kebijakan cost-sharing memiliki berbagai macam jenis, diantaranya adalah model yang sering digunakan dalam bisnis asuransi kesehatan terdiri atas: deductible, coinsurance, copayment, limitasi atau kombinasi dari berbagai model tersebut. asuransi sebelum biaya tersebut menjadi kewajiban badan pengelola asuransi. 
Coinsurance mewajibkan tertanggung membayar sejumlah persen tertentu dari biaya pelayanan kesehatan yang berlaku. Sedangkan copayment merupakan sejumlah biaya tertentu (flat) pada setiap jenis pelayanan yang harus dibayar oleh peserta (Manning and Marquis, 1996).

Skema asuransi sosial dan intervensi pengendalian biaya yang diterapkan di berbagai negara berbeda-beda tergantung kebijakan dari pemerintah negara tersebut, kebijakan yang berbeda-beda juga mungkin dapat memperlihatkan hasil yang berbeda pula, sehingga penting untuk melakukan penelitian ini dengan tujuan agar dapat mengetahui skema kebijakan pengendalian biaya yang diterapkan di berbagai negara sehingga dapat dilihat perbedaan yang dihasilkan dari kebijakan tersebut, selain itu juga ingin dilakukan eksplorasi dampak penerapan cost containment berdasarkan literatur yang telah diimplementasikan sebagai instrumen dari pengendalian biaya.

\section{Metode}

Studi literatur dilakukan secara sistematis dari artikel yang dipublikasikan tentang dampak implementasi iur biaya (costsharing); deductible, coinsurance, copayment, waiting period serta yang lainnya pada asuransi kesehatan nasional di berbagai negara. Pencarian dilakukan melalui database elektronik yaitu Proquest, Pubmed dan Chocrane Library. Manajemen basis data akan disiapkan dengan menggunakan perangkat lunak endnote ${ }^{\circledR}$, sementara proses peninjauan judul/abstrak dan teks lengkap akan dilakukan dengan menggunakan sistem Covidence ${ }^{\circledR}$ online.

Proses penelusuran artikel pada database elektronik menggunakan istilah yang terkait dengan PICO (Populasi, Intervensi, dan Outcome), selanjutnya disaring dengan bahasa yang digunakan dalam pelaporan serta ketersediaan artikel lengkap. Namun, penelusuran ini tidak dibatasi oleh metodologi dan desain studi yang digunakan. Oleh karena itu, semua jenis artikel yang dianalisis harus memenuhi syarat yang telah ditetapkan dalam kriteria inklusi disajikan pada tabel berikut:

Tabel 1. Strategi Penelusuran Berdasarkan PICO

\begin{tabular}{cll}
\hline \multicolumn{1}{c|}{ PICO } & \multicolumn{1}{c}{ Kriteria } & \multicolumn{1}{c}{ Kata Kunci } \\
\hline Population & $\begin{array}{l}\text { Seluruh studi yang menilai dampak dari iur biaya: } \\
\text { deductible, coinsurance, copayment dan waiting } \\
\text { period pada pelayanan kesehatan. }\end{array}$ & $\begin{array}{l}\text { Hanaged care } \\
\text { Manse; Universal coverage; }\end{array}$ \\
Intervention & $\begin{array}{l}\text { Seluruh skema pengendalian biaya termasuk } \\
\text { berbagai metode iur-biaya. }\end{array}$ & $\begin{array}{l}\text { Cost sharing; Deductible*; Coinsurance; } \\
\text { Copayment;Capping; Quota; Waiting } \\
\text { period* }\end{array}$ \\
Outcome & $\begin{array}{l}\text { Dampak yang terukur dari setiap skema } \\
\text { pengendalian biaya. }\end{array}$ & Utilization; Utilisation; Benefit \\
\hline
\end{tabular}

Teknik penelusuran :

(((((utilization) OR utilisation) OR benefit)) AND ((()(((cost sharing) OR deductible $\left.{ }^{\star}\right)$ OR coinsurance) OR copayment) OR capping) OR quota) OR waiting period $\left.\left.{ }^{\star}\right)\right)$ AND (((managed care) OR universal coverage) OR health insurance) Filters: Full text; Humans; English 
Kualitas dari studi ini akan dilakukan dengan penilaian oleh satu orang reviewer dan penilaian tersebut diperiksa kembali oleh satu orang reviewer lainnya. Setiap perselisihan akan diselesaikan dengan diskusi, dan melibatkan reviewer ketiga jika diperlukan.

\section{Hasil}

Penelusuran artikel dilakukan di database PubMed, Cochrane dan Porquest sesuai dengan kriteria PICO dan kata kunci yang sudah ditetapkan sebelumnya. Hasil penelusuran database secara ringkas disajikan pada tabel berikut:

Tabel 2. Strategi Penelusuran Berdasarkan PICO

\begin{tabular}{|c|c|c|c|c|}
\hline No & PICO & $\begin{array}{c}\text { Publikasi } \\
\text { database Pubmed }\end{array}$ & $\begin{array}{c}\text { Publikasi database } \\
\text { Cochrane }\end{array}$ & $\begin{array}{l}\text { Publikasi } \\
\text { database } \\
\text { Proquest }\end{array}$ \\
\hline A. & Population & & & \\
\hline 1 & Health insurance & 184.000 & 4.242 & 2.390 .795 \\
\hline 2 & Universal coverage & 6.497 & 288 & 409.791 \\
\hline 3 & Managed care & 70.021 & 5.445 & 1.486 .382 \\
\hline 4 & 1 or 2 or 3 & 552.867 & 1.124 .269 & 3.694 .675 \\
\hline B. & Intervention & & & \\
\hline 5 & Cost sharing & 7.196 & 514 & 1.555 .988 \\
\hline 6 & Deductible* & 2.180 & 65 & 346.550 \\
\hline 7 & Coinsurance & 1.827 & 53 & 19.321 \\
\hline 8 & Copayment & 614 & 70 & 12.737 \\
\hline 9 & Capping & 12.810 & 232 & 197.230 \\
\hline 10 & Quota & 2.034 & 114 & 468.469 \\
\hline 11 & Waiting period* & 6.545 & 2.259 & 994.386 \\
\hline $\begin{array}{l}12 \\
\text { C. }\end{array}$ & $\begin{array}{l}5 \text { or } 6 \text { or } 7 \text { or } 8 \text { or } 9 \text { or } 10 \text { or } \\
11 \\
\text { Outcome }\end{array}$ & 29.321 & 1.050 .162 & 3.096 .235 \\
\hline 13 & Utilization & 340.212 & 16.032 & 2.113 .341 \\
\hline 14 & Utilisation & 14.269 & 4.682 & 2.113 .341 \\
\hline 15 & Benefit & 393.362 & 82.335 & 14.295 .522 \\
\hline 16 & 13 or 14 or 15 & 401.887 & 406.956 & 15.412 .390 \\
\hline D. & Result & & & \\
\hline 17 & 4 and 12 and 16 & 2.736 & 51.714 & 722.833 \\
\hline 18 & $\begin{array}{l}\text { Limit to full text; humans; } \\
\text { english }\end{array}$ & 1.407 & 1.081 & 13.984 \\
\hline
\end{tabular}

Berdasarkan hasil pencarian pada tiga database utama, antara lain Proquest, Pubmed dan Cochrane Library diperoleh total sekitar 16.472 publikasi. Sebanyak 27 publikasi terseleksi sesuai dengan kriteria inklusi yang telah ditetapkan. Terdapat beberapa kriteria ekslusi yang paling umum ditemukan dalam proses penilaian, antara lain: publikasi tidak terkait dengan isu cost containment (cost sharing; capping; waiting period); tidak tersedia full text; desain studi tidak sesuai; dsb. Hasil PRISMA proses review yang dilakukan dapat dilihat pada Bagan 1. 


\section{Bagan 1. Jumlah Publikasi Hasil Penelusuran Database Sesuai Kriteria PICO}

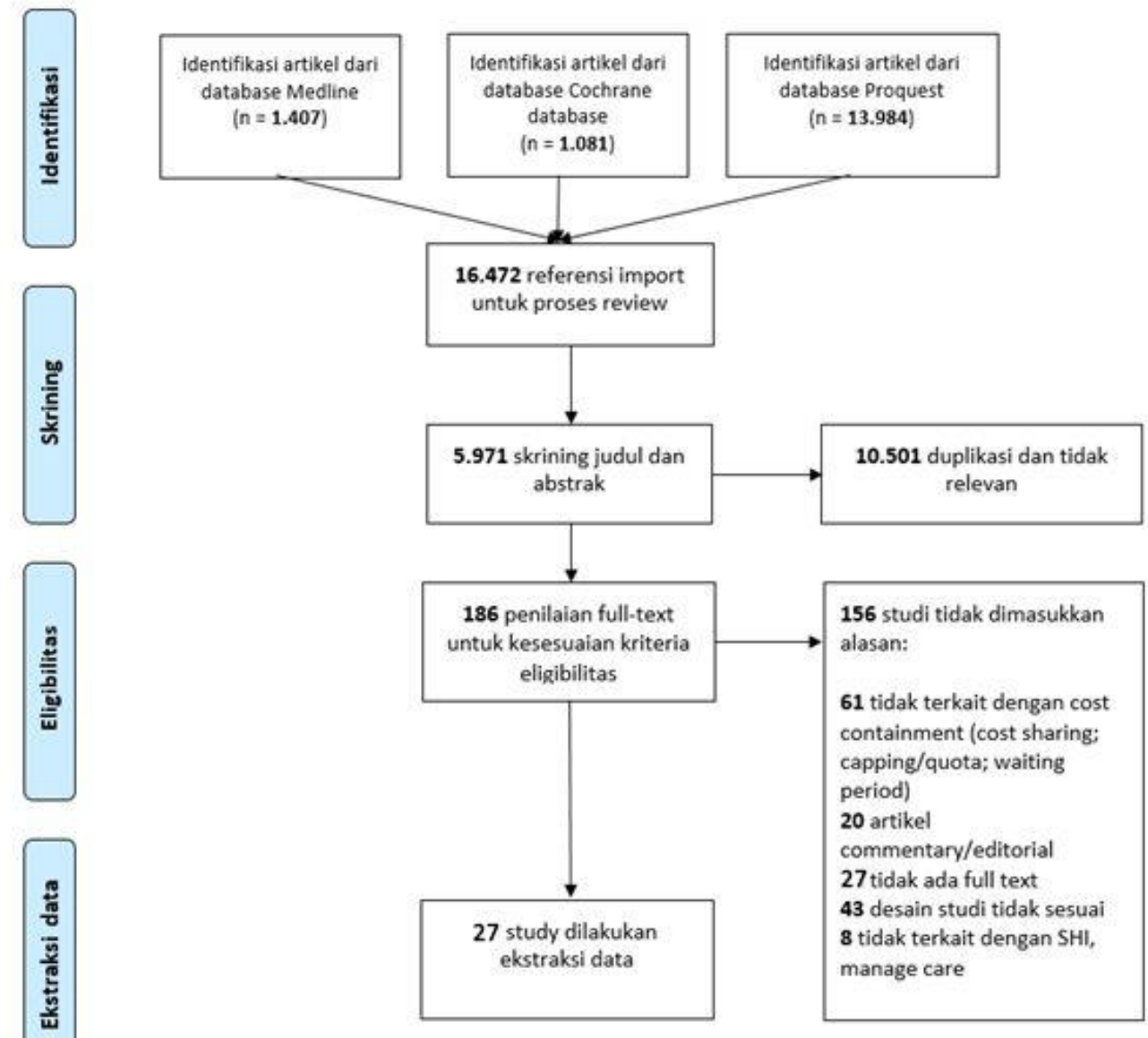

Terkait dengan karakteristik publikasi, tim peneliti mencoba untuk mengklasifikasikan dalam periode waktu dan regional (United States, Europe, Canada, Australia, Asia, dan Multi-Country). Jumlah publikasi yang sesuai dengan kriteria diketahui paling signifikan pada periode setelah tahun 2000. Sedangkan setting regional/Negara-negara yang menjadi unit penilaian paling banyak adalah Europe dan United States seperti yang digambarkan pada Bagan 2, sementara skema intervensi asuransi yang ditemukan dapat dilihat pada Bagan 3.

\section{Bagan 2. Distribusi Publikasi}

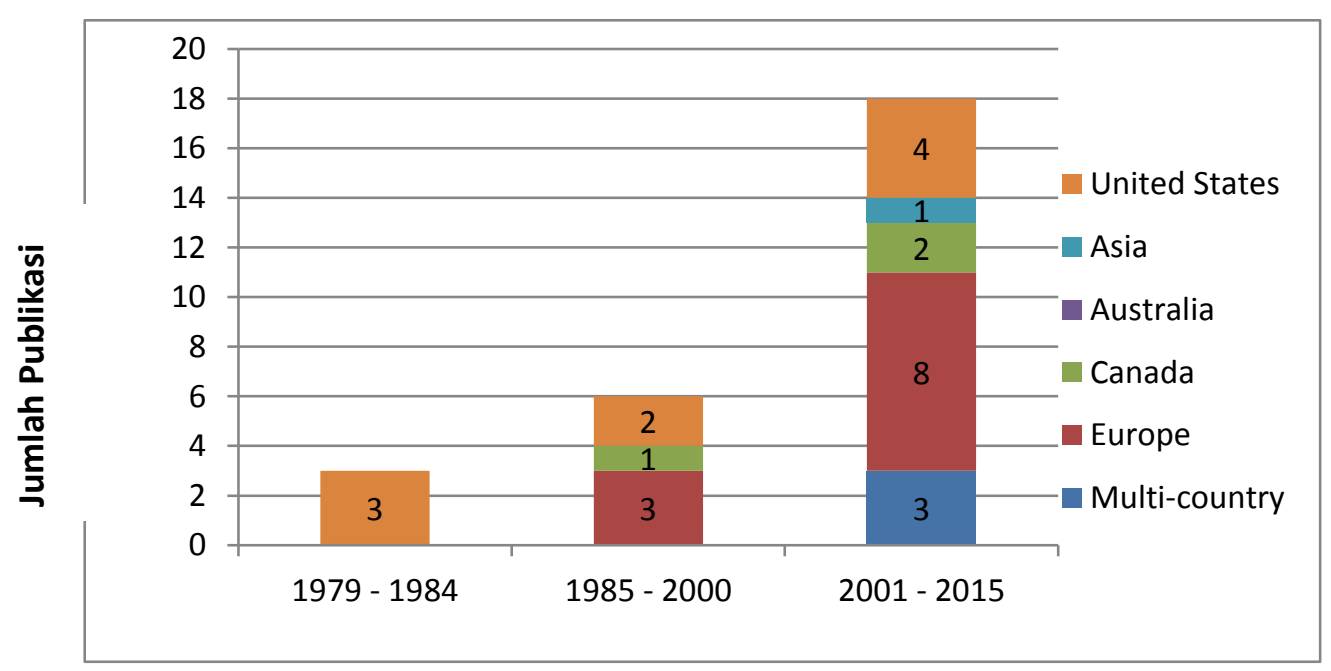

Tahun 


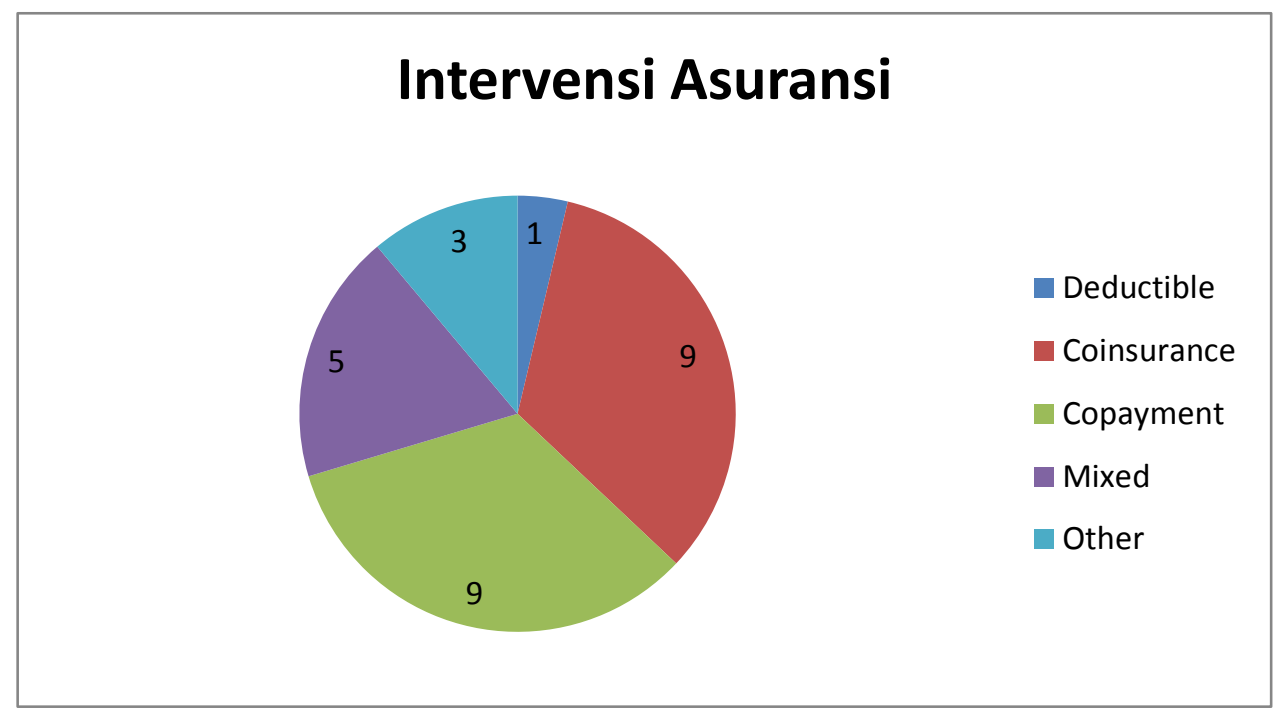

Secara lebih lanjut matriks yang menjelaskan mengenai studi mulai dari intervensi asuransi, pendekatan analitik, hingga hasil penelitian dari beberapa publikasi yang didapatkan terkait penerapan cost containment di berbagai negara dapat dilihat pada Tabel 3.

Tabel 3. Matriks Publikasi Cost Containment

\begin{tabular}{|c|c|c|c|c|c|c|}
\hline No & Study & Negara & Penyedia & $\begin{array}{c}\text { Intervensi } \\
\text { Asuransi }\end{array}$ & Pendekatan Analitik & Hasil Penelitian \\
\hline 1 & $\begin{array}{l}\text { (Babayan } \\
\text { and } \\
\text { Katzmann, } \\
1979)\end{array}$ & $\begin{array}{l}\text { United } \\
\text { States }\end{array}$ & $\begin{array}{l}\text { Medicare, } \\
\text { Medicaid, Blue } \\
\text { Cross, dan } \\
\text { asuransi } \\
\text { komersial } \\
\text { lainnya }\end{array}$ & Coinsurance & $\begin{array}{l}\text { Melakukan review } \\
\text { biaya secara periodik } \\
\text { dapat menggunakan } \\
\text { copy billing pasien } \\
\text { rumah sakit }\end{array}$ & $\begin{array}{l}\text { Pelayanan urologi dapat } \\
\text { menyumbang } 15 \% \text { dari } \\
\text { admisi rumah sakit, yang } \\
\text { dianggap sudah dapat } \\
\text { membantu rumah sakit jika } \\
\text { dibandingkan dengan } \\
\text { pengeluarannya }\end{array}$ \\
\hline 2 & $\begin{array}{l}\text { (Nelson, } \\
\text { Reeder } \\
\text { and } \\
\text { Dickson, } \\
\text { 1984) }\end{array}$ & $\begin{array}{l}\text { United } \\
\text { States }\end{array}$ & Medicaid & Copayment & $\begin{array}{l}\text { Melakukan } \\
\text { pengumpulan data dari } \\
\text { berkas klaim Medicaid: } \\
\text { South Carolina } \\
\text { (Program } \\
\text { Eksperimental) dan } \\
\text { Tennessee (Program } \\
\text { Kontrol) }\end{array}$ & $\begin{array}{l}\text { Jumlah copayment yang } \\
\text { tergolong kecil }(50 \phi) \text { untuk } \\
\text { pelayanan peresepan obat } \\
\text { merupakan kesuksesan } \\
\text { untuk mengontrol biaya } \\
\text { dalam program peresepan } \\
\text { obat Medicaid }\end{array}$ \\
\hline 3 & $\begin{array}{l}\text { (Allen, } \\
\text { 1984) }\end{array}$ & $\begin{array}{l}\text { California } \\
\text { (United } \\
\text { States) }\end{array}$ & $\begin{array}{l}\text { Social health } \\
\text { insurance: } \\
\text { preferred } \\
\text { provider, } \\
\text { health } \\
\text { planning, dan } \\
\text { self care }\end{array}$ & $\begin{array}{l}\text { Preferred } \\
\text { provider, } \\
\text { Health } \\
\text { planning, } \\
\text { Self care }\end{array}$ & $\begin{array}{l}\text { Melakukan } \\
\text { pengambilan random } \\
\text { sample dari total } 365 \\
\text { data orang dewasa dan } \\
\text { dilakukan interview }\end{array}$ & $\begin{array}{l}\text { Manfaat yang dihasilkan } \\
\text { dari tiap strategi berbeda- } \\
\text { beda sesuai dengan } \\
\text { masyarakat yang menjadi } \\
\text { sasaran, terdapat aspek } \\
\text { yang mempengaruhi yaitu } \\
\text { warna kulit, pendidikan, } \\
\text { usia, dan pendapatan }\end{array}$ \\
\hline 4 & $\begin{array}{l}\text { (Crane, } \\
\text { 1985) }\end{array}$ & $\begin{array}{l}\text { United } \\
\text { States }\end{array}$ & $\begin{array}{l}\text { National } \\
\text { health } \\
\text { insurance fund } \\
\text { dan } \\
\text { pemerintah } \\
\text { daerah }\end{array}$ & Coinsurance & $\begin{array}{l}\text { Melakukan analisa } \\
\text { melalui dokumen yang } \\
\text { telah tersedia }\end{array}$ & $\begin{array}{l}\text { Efisiensi biaya yang } \\
\text { dikeluarkan pemerintah } \\
\text { diimbangi oleh penerapan } \\
\text { program DRGs yang dapat } \\
\text { disesuaikan, akan tetapi } \\
\text { program DRGs hanya }\end{array}$ \\
\hline
\end{tabular}




\begin{tabular}{|c|c|c|c|c|c|c|}
\hline & & & & & & $\begin{array}{l}\text { digunakan untuk } \\
\text { pembayaran Medicare }\end{array}$ \\
\hline 5 & $\begin{array}{l}\text { (Donnelley, } \\
\text { 1989) }\end{array}$ & $\begin{array}{l}\text { United } \\
\text { States }\end{array}$ & Medicare & Coinsurance & $\begin{array}{l}\text { Melakukan analisa } \\
\text { melalui dokumen yang } \\
\text { telah tersedia }\end{array}$ & $\begin{array}{l}\text { Medicare saat ini } \\
\text { membayar harga untuk } \\
\text { rumah sakit berdasarkan } \\
\text { rata-rata baiya pelayanan } \\
\text { pasien dalam DRGs }\end{array}$ \\
\hline 6 & $\begin{array}{l}\text { (Anneman } \\
\text { s et al., } \\
\text { 1997) }\end{array}$ & $\begin{array}{l}\text { Belgium } \\
\text { (Europe) }\end{array}$ & $\begin{array}{l}\text { Social } \\
\text { security, } \\
\text { federal, } \\
\text { regional }\end{array}$ & Coinsurance & $\begin{array}{l}\text { Melakukan analisa } \\
\text { melalui dokumen yang } \\
\text { telah tersedia }\end{array}$ & $\begin{array}{l}\text { Terdapat } 2 \text { sistem yang } \\
\text { perlu dilibatkan untuk } \\
\text { mencapai kesuksesan yaitu } \\
\text { harus mengatahui } \\
\text { substitusi tiap bagian } \\
\text { pelayanan kesehatan dan } \\
\text { pengukuran farmasi tidak } \\
\text { bisa disolasi dari } \\
\text { pengeluaran lainnya, serta } \\
\text { peran evaluasi ekonomi } \\
\text { farmasi harus didefinisikan } \\
\text { dengan jelas }\end{array}$ \\
\hline 7 & $\begin{array}{l}\text { (Donev, } \\
\text { 1999) }\end{array}$ & $\begin{array}{l}\text { Macedon } \\
\text { ia } \\
\text { (Europe) }\end{array}$ & $\begin{array}{l}\text { Health } \\
\text { insurance } \\
\text { Fund } \\
\text { Committee }\end{array}$ & Copayment & $\begin{array}{l}\text { Melakukan analisa } \\
\text { melalui dokumen yang } \\
\text { telah tersedia }\end{array}$ & $\begin{array}{l}\text { Penerapan kebijakan baru } \\
\text { diharapkan dapat } \\
\text { memperkuat mekanisme } \\
\text { pendapatan untuk NHI, } \\
\text { serta memperkenalkan } \\
\text { copayment atau metode } \\
\text { pembayaran lainnya }\end{array}$ \\
\hline 8 & $\begin{array}{l}\text { (Davis, } \\
\text { 1999) }\end{array}$ & Canada & Pemerintah & Copayment & $\begin{array}{l}\text { Melakukan analisa } \\
\text { melalui dokumen yang } \\
\text { telah tersedia, dengan } \\
\text { melihat GDP dalam } \\
\text { pengeluaran kesehatan } \\
\text { serta status kesehatan } \\
\text { populasi }\end{array}$ & $\begin{array}{l}\text { Kebijakan cost containment } \\
\text { kedepannya diharapkan } \\
\text { dapat fokus mengatur cost } \\
\text { sektor privat dan } \\
\text { mengembangkan } \\
\text { pendekatan determinan } \\
\text { kesehatan }\end{array}$ \\
\hline 9 & $\begin{array}{l}\text { (Atella, } \\
\text { 2000) }\end{array}$ & $\begin{array}{l}\text { Italy } \\
\text { (Europe) }\end{array}$ & Pemerintah & Copayment & $\begin{array}{l}\text { Melakukan analisa } \\
\text { melalui dokumen yang } \\
\text { telah tersedia dari } \\
\text { tahun } 1963 \text { hingga } \\
1994\end{array}$ & 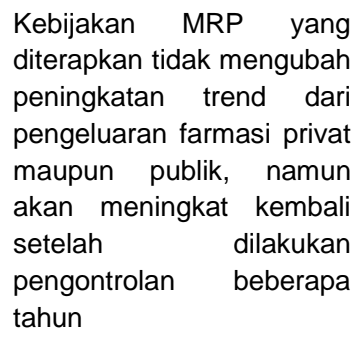 \\
\hline 10 & $\begin{array}{l}\text { (Andersen, } \\
\text { Smedby } \\
\text { and } \\
\text { Vagero, } \\
\text { 2001) }\end{array}$ & $\begin{array}{l}\text { Swedish } \\
\text { (Europe) }\end{array}$ & Pemerintah & Deductible & 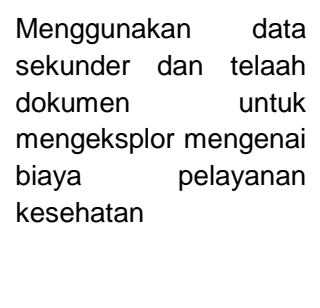 & $\begin{array}{l}\text { Pengendalian biaya di } \\
\text { Swedia diperkirakan } \\
\text { sukses, utamanya bukan } \\
\text { karena mekanisme pasar } \\
\text { tapi dari pengendalian } \\
\text { budget dan pengurangan } \\
\text { pelayanan yang dilakukan } \\
\text { pemerintah }\end{array}$ \\
\hline 11 & $\begin{array}{l}\text { (Breyer, } \\
\text { 2002) }\end{array}$ & $\begin{array}{l}\text { Germany } \\
\text { (Europe) }\end{array}$ & $\begin{array}{l}\text { The German } \\
\text { sickenss fund } \\
\text { system }\end{array}$ & $\begin{array}{l}\text { Coinsurance, } \\
\text { Copayment }\end{array}$ & $\begin{array}{lr}\text { Menggunakan data } \\
\text { sekunder dan telaah } \\
\text { dokumen } & \text { untuk } \\
\text { mengeksplor mengenai } \\
\text { biaya pelayanan } \\
\text { kesehatan dan data } \\
\text { demografi }\end{array}$ & $\begin{array}{lr}\text { Penting untuk } & \text { melakukan } \\
\text { pengkajian } & \text { kebijakan } \\
\text { misalnya } & \text { dengan } \\
\text { penerapan kriteria usia }\end{array}$ \\
\hline
\end{tabular}




\begin{tabular}{|c|c|c|c|c|c|c|}
\hline 12 & $\begin{array}{l}\text { (Blais et } \\
\text { al., 2003) }\end{array}$ & Canada & $\begin{array}{l}\text { Commission } \\
\text { de la con- } \\
\text { struction du } \\
\text { Que'bec } \\
\text { (CCQ) }\end{array}$ & $\begin{array}{l}\text { Coinsurance, } \\
\text { Deductible }\end{array}$ & $\begin{array}{lr}\text { Studi } & \text { Eksperimental } \\
\text { Case-Control: } & \text { Quebec } \\
\text { Health } & \text { Insurance } \\
\text { sebagai } & \text { intervensi dan } \\
\text { Private } & \text { Insurance } \\
\text { Company } & \text { sebagai } \\
\text { kontrol } & \end{array}$ & $\begin{array}{l}\text { Terdapat penurunan } \\
\text { rencana obat baru sebesar } \\
37 \% \text { dari konsumsi tiap } \\
\text { bulannya selama } 11 \text { bulan } \\
\text { belakangan }\end{array}$ \\
\hline 13 & $\begin{array}{l}\text { (Cunningh } \\
\text { am, 2005) }\end{array}$ & $\begin{array}{l}\text { United } \\
\text { States }\end{array}$ & Medicaid & Copayment & $\begin{array}{l}\text { Menggunakan data } \\
\text { sekunder dan telaah } \\
\text { dokumen pada } \\
\text { penelitian tahun } 2000- \\
2001 \text { dan } 2003 \\
\text { Community Tracking } \\
\text { Study (CTS) household } \\
\text { surveys }\end{array}$ & $\begin{array}{l}\text { Hasil penelitian } \\
\text { sebelumnya menunjukkan } \\
\text { efek negatif dari copayment } \\
\text { dan penerapan aturan } \\
\text { penggunaan peresepan } \\
\text { obat pada kategori } \\
\text { terapeutik yang luas }\end{array}$ \\
\hline 14 & $\begin{array}{l}\text { (Almarsdót } \\
\text { tir and } \\
\text { Traulsen, } \\
\text { 2005) }\end{array}$ & Europe & Pemerintah & Copayment & $\begin{array}{l}\text { Melakukan analisa } \\
\text { melalui dokumen yang } \\
\text { telah tersedia }\end{array}$ & $\begin{array}{lr}\text { Penerapan aturan dan } \\
\text { kebijakan yang dilakukan } \\
\text { untuk r mengatasi } \\
\text { peningkatan biaya farmasi } \\
\text { seperti meningkatkan } \\
\text { copay obat, implementasi } \\
\text { ini harus terus diikuti agar } \\
\text { mengetahui r manfaat } \\
\text { sesungguhnya r yang } \\
\text { dihasilkan }\end{array}$ \\
\hline 15 & $\begin{array}{l}\text { (Anis et al., } \\
\text { 2005) }\end{array}$ & Canada & Pemerintah & $\begin{array}{l}\text { Copayment, } \\
\text { Deductible }\end{array}$ & $\begin{array}{l}\text { Memilih populasi } \\
\text { penelitian berdasarkan } \\
\text { populasi kohort dengan } \\
\text { rheumatoid arthritis }\end{array}$ & $\begin{array}{l}\text { Sekitar } 18-20 \% \text { populasi } \\
\text { mencapai copayment } \\
\text { maksimal tahunan, } \\
\text { umumnya pasien hanya } \\
\text { sedikit yang mengambil } \\
\text { resep obat tapi } \\
\text { menggunakan banyak } \\
\text { pelayanan lainnya saat } \\
\text { penerapan } \\
\text { peresepan obat biaya }\end{array}$ \\
\hline 16 & $\begin{array}{l}\text { (The RAND } \\
\text { Corporatio } \\
\mathrm{n}, 2006 \text { ) }\end{array}$ & $\begin{array}{l}\text { United } \\
\text { states }\end{array}$ & $\mathrm{HMO}$ & Coinsurance & $\begin{array}{l}\text { Melakukan long-term } \\
\text { study dan studi } \\
\text { eksperimental yang } \\
\text { disebut sebagai Health } \\
\text { Insurance Experi- ment } \\
\text { (HIE) }\end{array}$ & $\begin{array}{l}\text { Cost sharing tidak secara } \\
\text { signifikan memberikan efek } \\
\text { pada kualitas dari } \\
\text { pelayanan yang didapatkan } \\
\text { oleh peserta, akan tetapi } \\
\text { terdapat peningkatan } \\
\text { penanganan yang baik dan } \\
\text { berguna untuk pasien yang } \\
\text { paling sakit dan pasien } \\
\text { yang paling miskin }\end{array}$ \\
\hline 17 & $\begin{array}{l}\text { (Davidova, } \\
\text { Praznovco } \\
\text { va and } \\
\text { Lundborg, } \\
\text { 2008) }\end{array}$ & $\begin{array}{l}\text { Sweden } \\
\text { and } \\
\text { Czech } \\
\text { (Europe) }\end{array}$ & $\begin{array}{l}\text { Czech: Public } \\
\text { Health } \\
\text { Insurance, } \\
\text { Sweden: } \\
\text { County } \\
\text { Council } \\
\text { Assistance }\end{array}$ & $\begin{array}{l}\text { Czech: } \\
\text { Copayment } \\
\text { dan Sweden: } \\
\text { Deductible }\end{array}$ & $\begin{array}{l}\text { Melakukan analisa } \\
\text { melalui dokumen yang } \\
\text { telah tersedia seperti } \\
\text { peraturan, laporan, } \\
\text { artikel ilmiah yang } \\
\text { dicari menggunakan } \\
\text { keyword }\end{array}$ & $\begin{array}{l}\text { Pada negara Sweden } \\
\text { terdapat harga maksimal } \\
\text { yang telah ditetapkan untuk } \\
\text { bahan farmasi dengan } \\
\text { adanya proses regulasi } \\
\text { harga dengan keputusan } \\
\text { reimbursement yand } \\
\text { ditetapkan Pharmaceutical } \\
\text { Benefits Board, namun } \\
\text { tidak diterapkan di Czech }\end{array}$ \\
\hline 18 & $\begin{array}{l}\text { (Chernew } \\
\text { et al., 2008) }\end{array}$ & $\begin{array}{l}\text { United } \\
\text { States }\end{array}$ & Pemerintah & Copayment & $\begin{array}{lr}\text { Menggunakan } & \text { model } \\
\text { ekonometrik } & \begin{array}{r}\text { untuk } \\
\text { menilai }\end{array} \\
\text { hubungan } \\
\text { antara } & \text { perubahan } \\
\text { copayment } & \text { obat dan }\end{array}$ & $\begin{array}{lr}\text { Pasien dengan pendapatan } \\
\text { yang rendah } & \text { akan lebih } \\
\text { sensitif } & \text { terhadap } \\
\text { perubahan } & \text { copayment } \\
\text { dibandingkan } & \text { pasien }\end{array}$ \\
\hline
\end{tabular}




\begin{tabular}{|c|c|c|c|c|c|c|}
\hline & & & & & $\begin{array}{l}\text { penanganan DM dan } \\
\text { CHF }\end{array}$ & $\begin{array}{l}\text { dengan pendapatan tinggi } \\
\text { atau menengah }\end{array}$ \\
\hline 19 & $\begin{array}{l}\text { (Burns, } \\
\text { 2009) }\end{array}$ & $\begin{array}{l}\text { United } \\
\text { States }\end{array}$ & Pemerintah & Coinsurance & $\begin{array}{l}\text { Menggunakan dua } \\
\text { bagian dari model } \\
\text { regresi untuk } \\
\text { mengestimasi } \\
\text { probabilitas dan level } \\
\text { pengeluaran Medicaid }\end{array}$ & $\begin{array}{l}\text { Secara rata-rata total } \\
\text { pengeluaran Medicaid per } \\
\text { bulan tidak berbeda antara } \\
\text { FFS dan MCO walaupun } \\
\text { beberapa pelayanannya } \\
\text { berbeda }\end{array}$ \\
\hline 20 & $\begin{array}{l}\text { (Averill et } \\
\text { al., 2010) }\end{array}$ & $\begin{array}{l}\text { England } \\
\text { (Europe) }\end{array}$ & Medicaid & $\begin{array}{l}\text { Pay for } \\
\text { performance, } \\
\text { best practice } \\
\text { pricing, price } \\
\text { discounting, } \\
\text { alignment of } \\
\text { incentives, } \\
\text { the medical } \\
\text { home, } \\
\text { payment by } \\
\text { episodes, } \\
\text { and provider } \\
\text { performance } \\
\text { reports are a } \\
\text { set of } \\
\text { payment } \\
\text { reforms that } \\
\text { can result in } \\
\text { lower costs, } \\
\text { better } \\
\text { coordination } \\
\text { of care, } \\
\text { improved } \\
\text { quality of } \\
\text { care, and } \\
\text { increased } \\
\text { consumer } \\
\text { involvement }\end{array}$ & $\begin{array}{l}\text { Melakukan analisa } \\
\text { melalui dokumen yang } \\
\text { telah tersedia }\end{array}$ & $\begin{array}{l}\text { Reformasi ini dapat } \\
\text { membuat simpanan } \\
\text { tahunan Medicare sebesar } \\
\$ 10 \text { billion dan } \\
\text { menciptakan framework } \\
\text { untuk simpanan } \\
\text { kedepannya }\end{array}$ \\
\hline 21 & $\begin{array}{l}\text { (Barham } \\
\text { and } \\
\text { Milliken, } \\
\text { 2010) }\end{array}$ & $\begin{array}{l}\text { Canada, } \\
\text { UK, rural } \\
\text { Australia } \\
\text { (Multi- } \\
\text { country) }\end{array}$ & $\begin{array}{l}\text { Fee-for- } \\
\text { service, } \\
\text { capitation, or a } \\
\text { mixed } \\
\text { mechanism }\end{array}$ & $\begin{array}{l}\text { Fee-for- } \\
\text { service, } \\
\text { capitation, or } \\
\text { a mixed } \\
\text { mechanism }\end{array}$ & 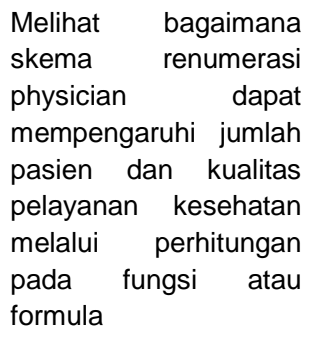 & $\begin{array}{l}\text { Saat tenaga medis menjadi } \\
\text { langka maka akan } \\
\text { membutuhkan banyak } \\
\text { biaya pula dalam } \\
\text { mengakses pelayanan } \\
\text { kesehatan untuk seluruh } \\
\text { masyrakat }\end{array}$ \\
\hline 22 & $\begin{array}{l}\text { (Aaltonen } \\
\text { et al., 2010) }\end{array}$ & $\begin{array}{l}\text { New } \\
\text { Zealand } \\
\text { and } \\
\text { Finlad } \\
\text { (Multi- } \\
\text { country) }\end{array}$ & $\begin{array}{l}\text { Pharmaceutic } \\
\text { al Pricing } \\
\text { Board } \\
\text { (Ministry of } \\
\text { Social Affairs } \\
\text { and Health) }\end{array}$ & Copayment & $\begin{array}{l}\text { Melakukan analisa } \\
\text { melalui dokumen yang } \\
\text { telah tersedia dari } \\
\text { MIMS New Ethicals } \\
2007 \text { Isuue } 6 \text { (New } \\
\text { Zealand) dan Pharma } \\
\text { Fennica } 2007 \text { (Finland) }\end{array}$ & $\begin{array}{l}\text { Masyarakat yang berhasil } \\
\text { disubsidi sebesar } 30,9 \% \text { di } \\
\text { Finland dan } 29,5 \% \text { di New } \\
\text { Zealand, proporsi } \\
\text { masyarakat yang disubsidi } \\
\text { secara penuh lebih besar di } \\
\text { New Zealand dibandingkan } \\
\text { di Finland, adapun } \\
\text { masyarakat yang disubsidi } \\
\text { penuh adalah umumnya } \\
\text { usia lanjut }\end{array}$ \\
\hline 23 & $\begin{array}{l}\text { (Chang, } \\
\text { 2011) }\end{array}$ & $\begin{array}{l}\text { Taiwan } \\
\text { (Asia) }\end{array}$ & $\begin{array}{l}\text { Taiwan's } \\
\text { National } \\
\text { Health }\end{array}$ & Coinsurance & $\begin{array}{l}\text { Melakukan analisa } \\
\text { melalui dokumen yang } \\
\text { telah tersedia }\end{array}$ & $\begin{array}{l}\mathrm{NHI} \text { menurunkan bahaya } \\
\text { mortalitas pada wanita tua } \\
\text { yang sebelumnya tidak } \\
\text { diasuransikan }\end{array}$ \\
\hline
\end{tabular}




\begin{tabular}{|c|c|c|c|c|c|c|}
\hline & & & $\begin{array}{l}\text { Insurance } \\
(\mathrm{NHI})\end{array}$ & & & \\
\hline 24 & $\begin{array}{l}\text { (Athanasak } \\
\text { is et al., } \\
\text { 2011) }\end{array}$ & $\begin{array}{l}\text { Greece } \\
\text { (Europe) }\end{array}$ & $\begin{array}{l}\text { Greek Social } \\
\text { Health } \\
\text { Insurance } \\
\text { (SHI) }\end{array}$ & Coinsurance & $\begin{array}{l}\text { Melakukan perhitungan } \\
\text { dengan model } \\
\text { matematika untuk } \\
\text { mengestimasi } \\
\text { berkurangnya nilai } \\
\text { pasien coinsurance }\end{array}$ & $\begin{array}{l}\text { Berkurangnya rate pasien } \\
\text { coinsurance dari } 25 \% \\
\text { menjadi } 0 \% \text { disebabkan } \\
\text { peningkatan pada OAA } \\
\text { sebesar } 30,5 \%\end{array}$ \\
\hline 25 & $\begin{array}{l}\text { (Da Roit, } \\
\text { 2012) }\end{array}$ & $\begin{array}{l}\text { Netherla } \\
\text { nd } \\
\text { (Europe) }\end{array}$ & $\begin{array}{l}\text { National LTC } \\
\text { insurance } \\
\text { system }\end{array}$ & Copayment & $\begin{array}{ll}\text { Melakukan } & \text { review } \\
\text { sistematis, } & \text { analisa } \\
\text { statistik, dan analisa } \\
\text { kebijakan }\end{array}$ & $\begin{array}{lr}\text { Pengenalan } & \text { tanggung } \\
\text { jawab keuangan individu } \\
\text { dan kewajiban perawatan } \\
\text { keluarga } \\
\text { menunjukkan potensi untuk } \\
\text { mengurangi beberapa } \\
\text { tanggungan } \\
\text { mendorong } \\
\text { kesehatan yang informal }\end{array}$ \\
\hline 26 & $\begin{array}{l}\text { (Andersen, } \\
\text { 2013) }\end{array}$ & $\begin{array}{l}\text { Denmark } \\
\text { and } \\
\text { Norwegia } \\
\text { (Europe) }\end{array}$ & $\begin{array}{l}\text { Regions/publi } \\
\text { c health } \\
\text { insurance }\end{array}$ & Coinsurance & $\begin{array}{l}\text { Melakukan penelitian } \\
\text { berdasarkan kebijakan, } \\
\text { dokumen, analisa yang } \\
\text { pernah dilakukan dan } \\
\text { menganalisa } 360 \text { artikel } \\
\text { koran }\end{array}$ & $\begin{array}{lr}\text { Pengukuran } & \text { cost } \\
\text { containment } & \text { terhadap } \\
\text { physicians } & \text { lebih lemah di } \\
\text { Denmark } & \text { dibandingkan } \\
\text { Norwegia, } & \text { sedangkan } \\
\text { terhadap non medical } \\
\text { professions lebih lemah di } \\
\text { Norwegia dibandingkan } \\
\text { Denmark }\end{array}$ \\
\hline 27 & $\begin{array}{l}\text { (Barnieh et } \\
\text { al., 2014) }\end{array}$ & $\begin{array}{l}\text { Europe, } \\
\text { North } \\
\text { America, } \\
\text { Latin } \\
\text { America } \\
\text { and } \\
\text { Australas } \\
\text { ia (Multi- } \\
\text { country) }\end{array}$ & Pemerintah & $\begin{array}{l}\text { Deductible } \\
\text { (Denmark, } \\
\text { the } \\
\text { Netherlands, } \\
\text { Sweden, and } \\
\text { Medicare } \\
\text { part D), } \\
\text { Copayment } \\
\text { Australia, } \\
\text { Belgium, } \\
\text { Czech } \\
\text { Republic, } \\
\text { England, } \\
\text { Estonia, } \\
\text { Greece, } \\
\text { Hungary, } \\
\text { Italy, Japan, } \\
\text { New } \\
\text { Zealand, } \\
\text { Norway, } \\
\text { Slovenia, } \\
\text { South Korea, } \\
\text { Spain, and } \\
\text { Turkey) }\end{array}$ & $\begin{array}{l}\text { Menggunakan data dari } \\
\text { negara OECD sebagai } \\
\text { sampel pada penelitian }\end{array}$ & $\begin{array}{l}\text { Terdapat berbagai variabel } \\
\text { yang digunakan untuk cost } \\
\text { containment untuk } \\
\text { membatasi pengeluaran } \\
\text { farmasi, perlu dilakukan } \\
\text { penelitian lebih lanjut untuk } \\
\text { mengetahui penanganan } \\
\text { biaya yang lebih tepat }\end{array}$ \\
\hline
\end{tabular}

\section{Diskusi}

Dalam proses penilaian/review artikel secara umum diketahui bahwa terdapat dua kategori intervensi pengendalian biaya (cost containment) yang telah banyak dilakukan yaitu diinisiasi oleh penyedia layanan kesehatan dan diinisiasi oleh pemerintah/pembayar dalam konteks asuransi sosial.
Skema cost containment yang diinisiasi penyedia layanan kesehatan dapat berupa modifikasi pedoman klinis, manajemen obat, hingga pengaturan sumber daya manusia di rumah sakit. Sementara skema cost containment dari perspektif pemerintah dapat berupa modifikasi sistem pembayaran; cost sharing; capping/quota; waiting period. Dalam kajian ini, 
proses penilaian difokuskan pada skema cost containment dari perspektif pemerintah/pembayar, sehingga beberapa publikasi terkait dengan cost containment provider atau layanan kesehatan telah dieksklusi. Skema yang paling banyak ditemukan adalah cost sharing, dimana secara teori dapat berupa copayment, deductible, dan coinsurance. Diantara 3 jenis cost sharing beserta metode lainnya, berdasarkan Bagan 3 dapat dilihat bahwa yang paling banyak digunakan dalam pelayanan kesehatan di berbagai negara adalah skema intervensi asuransi coinsurance dan copayment yang masing-masing ditemukan di 9 dari 27 penelitian.

Masing-masing negara yang menjadi referensi dari penelitian menerapkan skema cost containment yang sangat bervariasi, baik yang menerapkan skema cost containment tunggal, maupun kombinasi. Contoh penelitian yang menggunakan penerapan skema kombinasi adalah di Canada pada penelitian Anis di tahun 2005 yang pada saat itu menerapkan skema copayment dan deductible, serta di Germany pada penelitian Breyer di tahun 2002 yang pada saat itu menerapkan skema coinsurance dan copayment. Secara prinsip, penerapan skema cost containment diharapkan mampu mendorong penurunan utilisasi pelayanan kesehatan yang tidak esensial dari segi pengendalian biaya. Dengan kata lain, dapat menurunkan risiko moral hazard dari perspektif peserta dengan adanya kontribusi tambahan atas pemanfaatan layanan kesehatan yang tidak dibutuhkan. Berdasarkan penelitian yang ditemukan, terdapat beberapa efek positif yang dihasilkan dari penerapan cost containment berupa cost sharing, yaitu diantaranya pada penelitian Babayan dan Katzmann di tahun 1979 menjelaskan bahwa pelayanan kesehatan mendapatkan pendapatan yang cukup sehingga tidak mengalami kerugian karena pemasukan yang kurang memadai, namun perlu dikaji dengan baik mengenai nominal yang diterapkan karena akan memberikan dampak terutama pada pasien dengan pendapatan rendah. Selain efek positif, terdapat pula beberapa efek samping lain yang ditimbulkan dari penerepan cost sharing, seperti pada penelitian Anis di tahun 2005 menjelaskan bahwa penerapan copayment yang membuat pasien yang mengambil resep obat berkurang karena adanya biaya copay farmasi yang harus dibayarkan oleh peserta atau pasien. Oleh karena itu pemerintah atau lembaga lainnya yang memiliki tanggung jawab terhadap pemenuhan universal health coverage di suatu negara harus melakukan pengkajian dengan baik dalam upaya menerapkan salah satu bentuk pengendalian biaya (cost containment) untuk menciptakan hasil yang lebih efisien dan tidak memberikan kerugian pada pihak manapun.

\section{Kesimpulan dan Saran}

Penerapan skema cost-sharing di beberapa negara terdiri dari berbagai macam jenis, berdasarkan hasil penelitian dapat dilihat bahwa skema cost-sharing yang paling sering digunakan adalah copayment, deductible, dan coinsurance. Implementasi cost-sharing akan memberikan beberapa keuntungan diantaranya adalah: dapat mengurangi pengeluaran obat dengan turunnya utilisasi layanan kesehatan, dan mengalihkan sebagian porsi pengeluaran pemerintah provinsi kepada peserta/ masyarakat; program ini mampu mendorong pola pemanfaatan obat yang lebih sesuai, atau mengurangi penggunaan obat-obat yang tidak esensial; secara tidak langsung akan meningkatkan technical efficiency pada market obat dengan semakin pedulinya peserta/masyarakat dalam pemanfaatan obat.

\section{Daftar Pustaka}

Aaltonen, K. et al. (2010) 'The impact of pharmaceutical cost containment policies on the range of medicines available and subsidized in Finland and New Zealand', Value in Health. International Society for Pharmacoeconomics and Outcomes Research (ISPOR), 13(1), pp. 148-156. doi: 10.1111/j.1524-4733.2009.00598.x.

Aden, C. M. (2012) Kendali Biaya \& Kendali Mutu dalam Managed Care', Tesis Universitas Gadjah Mada. Available at: file:///H:/Kerjaan PA/JEKI/Referensi tambahan revisi/Mutu Pelayanan Kesehatan.html (Accessed: 10 January 2019).

Allen, H. M. (1984) 'Consumers and choice: cost containment strategies for health care provision', Health psychology: official journal of the Division of Health 
Psychology, American Psychological Association, 3(5), pp. 411-430. doi: 10.1037/0278-6133.3.5.411.

Almarsdóttir, A. B. and Traulsen, J. M. (2005) 'Cost-containment as part of pharmaceutical policy', Pharmacy World and Science, 27(3), pp. 144-148. doi: 10.1007/s11096-005-6953-6.

Andersen, L. B. (2013) 'Health care cost containment in Denmark and Norway: A question of relative professional status?', Health Economics, Policy and Law, 9(2), pp. 169-191. doi: 10.1017/S1744133113000248.

Andersen, R., Smedby, B. and Vagero, D. (2001) 'Cost containment, solidarity and cautious experimentation: Swedish dilemmas', Social Science and Medicine, 52(8), pp. 1195-1204. doi: 10.1016/S0277-9536(00)00239-2.

Anis, A. H. et al. (2005) 'When patients have to pay a share of drug costs: Effects on frequency of physician visits, hospital admissions and filling of prescriptions', Cmaj, 173(11), pp. 1335-1339. doi: 10.1503/cmaj.045146.

Annemans, L. et al. (1997) 'Pricing and reimbursement of pharmaceuticals in Belgium', PharmacoEconomics, 11(3), pp. 203-209. doi: 10.2165/00019053199711030-00001.

Ascobat Gani, Pembiayaan Kesehatan di Indonesia, dibacakan pada seminar Sistem Pembayaran Kapitasi, Jakarta, 1996.

Atella, V. (2000) 'Drug cost containment policies in Italy: Are they really effective in the long-run? The case of minimum reference price', Health Policy, 50(3), pp. 197-218. doi: 10.1016/S01688510(99)00070-6.

Athanasakis, K. et al. (2011) 'Abolishing coinsurance for oral antihyperglycemic agents: Effects on social insurance budgets', American Journal of Managed Care, 17(2), pp. 130-135.

Averill, R. F. et al. (2010) 'Achieving cost control, care coordination, and quality improvement through incremental payment system reform', Journal of
Ambulatory Care Management, 33(1), pp. 2-23. doi: 10.1097/JAC.0b013e3181c9f437.

Babayan, R. K. and Katzmann, B. (1979) 'The Catch-22's of cost containment', Journal of Urology. The American Urological Association Education and Research, Inc., 122(3), pp. 283-286. doi: 10.1016/S0022-5347(17)56368-5.

Barham, V. and Milliken, O. (2010) 'Payment mechanism and the composition of physician practices: Balancing costcontainment, access, and quality of care', Health economics, 19(11), pp. 13001317. doi: 10.1002/hec.

Barnieh, L. et al. (2014) 'A systematic review of cost-sharing strategies used within publicly-funded drug plans in member countries of the organisation for economic co-operation and development', PLoS ONE, 9(3). doi: 10.1371/journal.pone.0090434.

Blais, L. et al. (2003) 'Impact of a cost sharing drug insurance plan on drug utilization among individuals receiving social assistance', Health Policy, 64(2), pp. 163-172. doi: 10.1016/S01688510(02)00158-6.

Breyer, F. (2002) 'Reimbursement and Cost Containment', Decoding History, pp. 5568. doi: 10.1057/9780230510142_4.

Burns, M. E. (2009) 'Medicaid managed care and cost containment in the adult disabled population', Medical Care, 47(10), pp. 1069-1076. doi: 10.1097/MLR.0b013e3181a80fef.

Chang, S. (2011) 'The Effect of Taiwan's National Health Insurance on Mortality of The Elderly: Revisited', Health economics, 19(11), pp. 1300-1317. doi: 10.1002/hec.

Chernew, M. et al. (2008) 'Effects of increased patient cost sharing on socioeconomic disparities in health care', Journal of General Internal Medicine, 23(8), pp. 1131-1136. doi: 10.1007/s11606-008-0614-0.

Counte, M. A. et al. (2019) 'Global Advances in Value-Based Payment and Their Implications for Global Health 
Management Education, Development, and Practice', Frontiers of health services management, 6(January), pp. 1-7. doi: 10.3389/fpubh.2018.00379.

Crane, T. S. (1985) 'Hospital costs control in Norway: A decade's experience with prospective payment', Public Health Reports, 100(4), pp. 406-417.

Cunningham, P. J. (2005) 'Market watch: Medicaid cost containment and access to prescription drugs', Health Affairs, 24(3), pp. 780-789. doi: 10.1377/hlthaff.24.3.780.

Davidova, J., Praznovcova, L. and Lundborg, C. S. (2008) 'Pricing and reimbursement of pharmaceuticals in the Czech Republic and Sweden', Pharmacy World and Science, 30(1), pp. 57-64. doi: 10.1007/s11096-007-9141-z.

Davis, J. B. (1999) 'Cost containment mechanisms in Canada', Croatian Medical Journal, 40(2), pp. 287-293.

Donev, D. M. (1999) 'Health insurance system in the Republic of Macedonia', Croatian Medical Journal, 40(2), pp. 175-180.

Donnelley, S. (1989) 'Cost Containment, DRGs, and The Ethics of Health Care', Hastings Center, 19(1), pp. 5-6.

Feldhaus, I. and Mathauer, I. (2018) 'Effects of mixed provider payment systems and aligned cost sharing practices on expenditure growth management, efficiency, and equity: A structured review of the literature', BMC Health Services Research. BMC Health Services Research, 18(1), pp. 1-15. doi: 10.1186/s12913-018-3779-1.

Hadiyati, I. et al. (2017) 'Konsep Kualitas Pelayanan Kesehatan berdasar atas Ekspektasi Peserta Jaminan Kesehatan
Nasional', $\quad M K B, \quad 49(2) . \quad$ doi: http://dx.doi.org/10.15395/mkb.v49n2.1 054 Konsep.

Heryana, A. (2013) 'Moral Hazard dalam Asuransi Kesehatan', pp. 1-9.

Janis, N. (no date) BPJS Kesehatan, Supply, dan Demand Terhadap Layanan Kesehatan.

Manning, W. G. and Marquis, S. (1996) 'Health insurance: the tradeoff between risk pooling and moral hazard', Journal of health economics, 15, pp. 609-639. doi: 10.1016/s0167-6296(96)00497-3.

Nelson, A., Reeder, E. and Dickson, M. (1984) 'The Effect of a Medicaid Drug Copayment Program on the Utilization and Cost of Prescription Services', Medical care, 22.

Da Roit, B. (2012) 'The Netherlands: The struggle between universalism and cost containment', Health and Social Care in the Community, 20(3), pp. 228-237. doi: 10.1111/j.1365-2524.2011.01050.x.

Setyawan, F. E. B. (2015) 'Sistem Pembiayaan Kesehatan', 11(2), pp. 360362.

Tangcharoensathien, V. et al. (2018) 'Health systems development in Thailand: a solid platform for successful implementation of universal health coverage', The Lancet. Elsevier Ltd, 391(10126), pp. 1205-1223. doi: 10.1016/S01406736(18)30198-3.

The RAND Corporation (2006) 'The Health Insurance Experiment: A Classic RAND Study Speaks to the Current Health Care Reform Debate', RAND Health, pp. 1-7. Available at: http://www.rand.org/ content/dam/rand/pubs/research_briefs/2 006/RAND_RB9174.pdf. 